\title{
Forest production predicted from satellite image analysis for the Southeast Asia region
}

\author{
Christopher Potter $^{1 *}$, Steven Klooster ${ }^{2}$, Vanessa Genovese ${ }^{2}$ and Cyrus Hiatt ${ }^{2}$
}

\begin{abstract}
Background: The objective of this study was to demonstrate a new, cost-effective method to define the sustainable amounts of harvested wood products in Southeast Asian countries case studies, while avoiding degradation (net loss) of total wood carbon stocks. Satellite remote sensing from the MODIS sensor was used in the CASA (Carnegie Ames Stanford Approach) carbon cycle model to map forest production for the Southeast Asia region from 2000 to 2010. These CASA model results have been designed to be spatially detailed enough to support carbon cycle assessments in different wooded land cover classes, e.g., open woodlands, wetlands, and forest areas.

Results: The country with the highest average forest net primary production (NPP greater than $950 \mathrm{~g} \mathrm{C} \mathrm{m}^{-2} \mathrm{yr}^{-1}$ ) over the period was the Philippines, followed by Malaysia and Indonesia. Myanmar and Vietnam had the lowest average forest NPP among the region's countries at less than $815 \mathrm{~g} \mathrm{C} \mathrm{m}^{-2} \mathrm{yr}^{-1}$. Case studies from throughout the Southeast Asia region for the maximum harvested wood products amount that could be sustainably extracted per year were generated using the CASA model NPP predictions.

Conclusions: The method of using CASA model's estimated annual change in forest carbon on a yearly basis can conservatively define the upper limit for the amount of harvested wood products that can be removed and still avoid degradation (net loss) of the total wood carbon stock over that same time period.
\end{abstract}

Keywords: Southeast Asia, Forest production, Harvested wood products, Carbon cycle, MODIS

\section{Background}

Net primary production (NPP) by vegetation provides the chemical energy that drives most biotic processes on Earth. NPP represents much of the carbon that is consumed by microbes and animals. Climate controls on plant production are an issue of central relevance to society, mainly because of concerns about the extent to which NPP in managed ecosystems can provide human populations with adequate forage and fiber products. In areas where NPP is not harvested for human use, the carbon in dead plant biomass naturally returns to the atmosphere mainly as $\mathrm{CO}_{2}$ from decomposition by microbial respiration.

As a monitoring tool for forest management projects, annual NPP flux of atmospheric carbon $\left(\right.$ as $\left.\mathrm{CO}_{2}\right)$ into standing wood pools represents the yearly increment added to a managed area, which may also include wood harvest activity and extraction of older forest carbon.

\footnotetext{
* Correspondence: chris.potter@nasa.gov

${ }^{1}$ NASA Ames Research Center, Moffett Field, CA, USA

Full list of author information is available at the end of the article
}

Allocation of carbon to standing wood pools in tropical forests measured worldwide was found to average 39\% \pm $10 \%$ of NPP flux [1]. When totaled over a defined project boundary area, an increasing trend in annual NPP and wood $\mathrm{C}$ turnover time favors net storage of atmospheric $\mathrm{CO}_{2}$ within a forest ecosystem (Luo et al. [2]).

In this study, we summarized results from the CASA (Carnegie-Ames-Stanford Approach) model for forest ecosystem NPP across all the countries of Southeast Asia region from 2000 to 2010. The main purpose of the study was to define the upper limit for the amount of harvested wood products that can be removed by logging in selected case studies and still avoid degradation (net loss) of the total wood carbon stock. Direct input of satellite vegetation index "greenness" data from the NASA moderate resolution imaging spectroradiometer (MODIS) satellite sensor into the CASA simulation model was used to estimate spatial variability in annual NPP at a ground resolution of $8-\mathrm{km}[3,4]$. These CASA model results have been designed to be spatially detailed enough to support carbon

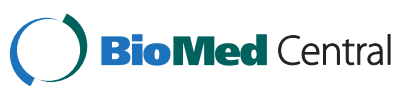


cycle assessments in different wooded land cover classes, e.g., open woodlands, wetlands, and forest areas.

\section{Regional study area}

Both Potter et al. [5] and Zhao and Running [6] estimated that the Southeast Asia region accounted for over $25 \%$ of all NPP in the tropical rainforest zones globally, with a total regional NPP flux of around $3.7 \mathrm{Pg}\left(10^{15} \mathrm{~g}\right)$ $\mathrm{C}$ per year. Miettinen et al. [7] reported an overall 1.0\% yearly decline in forest cover in insular Southeast Asia between 2000 and 2010, with the main change trajectories to plantations and secondary vegetation. Peat swamp forests experienced the highest deforestation rates at an average annual rate of $2.2 \%$, while lowland evergreen forest area declined by $1.2 \%$ per year.

Among the 30 leading countries listed for area of forest loss annually by the Food and Agriculture Organization (FAO) of the United Nations and by Potter et al. [8], seven of these nations were located in the Southeast Asia region, namely Myanmar, Indonesia, Malaysia, Vietnam, Cambodia, Laos, and Papua New Guinea (in order of highest to lowest). These countries, along with the Philippines and Thailand, comprise the Southeast Asia region for the present study.

\section{Results and discussion}

All of the countries in the Southeast Asia region had 75\% or greater of their total forest and open woodland areas classified in the CASA model as evergreen broadleaf forest types, with the exception of Cambodia (at 61\%). Indonesia, Laos, Malaysia, Papua New Guinea, and the Philippines each had over $92 \%$ of their total forested land classified as evergreen broadleaf types, which put a focus on comparison of NPP in this forest class among the countries listed in Table 1.

Results of the CASA model indicated that the country with the highest average forest NPP (greater than $950 \mathrm{~g} \mathrm{C}$ $\mathrm{m}^{-2} \mathrm{yr}^{-1}$ ) over the period 2000 to 2010 was the Philippines, followed by Malaysia and Indonesia (Table 1). Myanmar and Vietnam had the lowest average forest NPP among the region's countries (less than $815 \mathrm{~g} \mathrm{C} \mathrm{m}^{-2} \mathrm{yr}^{-1}$ ).

Maps of mean annual NPP and standard deviation of annual NPP (2000 - 2010) showed specific forest areas within these countries with the highest estimated NPP at greater than $1100 \mathrm{~g} \mathrm{C} \mathrm{m}^{-2} \mathrm{yr}^{-1}$ (Figure 1a). These areas included the southern Philippines, particularly the eastern and southern sections of the island of Mindanao, the Khao Luang mountain range in southern Thailand, and most forested areas of Sumatra and western Kalimantan. Classification by natural breaks (Jenks' optimization) into low, moderate, and high production forest categories delineated these areas more clearly (Figure 2). This categorization method minimized each class's average deviation from the class mean, while maximizing each class's deviation from the means of the other groups [9].

Forest areas within these countries with the highest estimated variation from year to year in annual NPP fluxes were detected in western coastal Myanmar, southern Vietnam, central Malaysia, eastern Sumatra, and northeastern Borneo (Figure 1b). The standard deviation of the mean NPP in each of these forested areas exceeded $50 \mathrm{~g} \mathrm{C} \mathrm{m}^{-2} \mathrm{yr}^{-1}$.

Estimating the annual biomass increment has been a consistent reporting requirement in all Intergovernmental Panel on Climate Change (IPCC) Guidelines, which imply that above ground biomass can be estimated in an acceptable manner with remote sensing techniques and ecosystem models (IPCC, [10]). To calculate the annual change in carbon stock storage in forests $\left(\Delta \mathrm{C}_{\mathrm{LUi}}\right)$, IPCC Guidelines offer the following equation:

$$
\Delta \mathrm{C}_{\mathrm{LUi}}=\Delta \mathrm{C}_{\mathrm{AB}}+\Delta \mathrm{C}_{\mathrm{BB}}+\Delta \mathrm{C}_{\mathrm{DW}}+\Delta \mathrm{C}_{\mathrm{LI}}+\Delta \mathrm{C}_{\mathrm{SO}}+\Delta \mathrm{C}_{\mathrm{HWP}}
$$

where

$\Delta \mathrm{C}_{\mathrm{AB}}$ is the annual change in carbon stock storage in above ground biomass;

Table 1 CASA model predictions of mean annual NPP from 2000 to 2010 for Southeast Asia countries by forest, savanna, and wetland land cover classes

\begin{tabular}{lllll}
\hline & Evergreen broadleaf forests & Evergreen needleleaf forests & Mixed forests & Open woodlands and savannas \\
\hline Country & & & & 638 \\
Myanmar & 782 & 614 & 663 & 742 \\
Cambodia & 861 & 726 & 383 & 747 \\
Indonesia & 953 & 547 & 737 & 761 \\
Laos & 878 & 837 & 882 & 903 \\
Malaysia & 970 & 443 & & 757 \\
Papua New Guinea & 916 & 818 & 968 & 989 \\
Philippines & 1108 & 662 & 714 & 727 \\
Vietnam & 812 & 490 & 647 & 718 \\
Thailand & 862 & 704 & &
\end{tabular}

All fluxes were reported in units of $\mathrm{g} \mathrm{C}^{-2} \mathrm{yr}^{-1}$. 


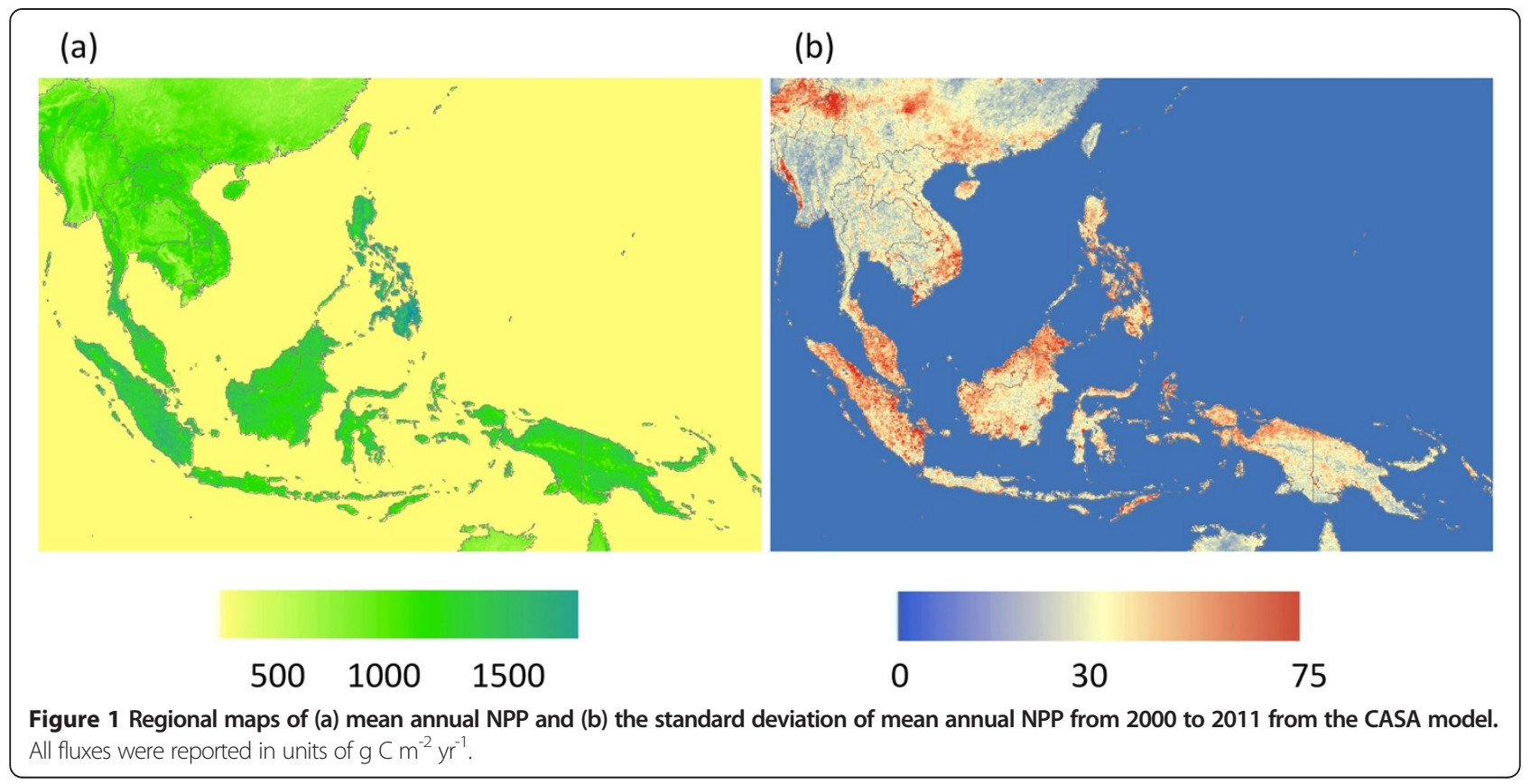

$\Delta \mathrm{C}_{\mathrm{BB}}$ is the annual change in carbon stock storage in below ground biomass;

$\Delta \mathrm{C}_{\mathrm{DW}}$ is the annual change in carbon stock storage in dead wood;

$\Delta \mathrm{C}_{\mathrm{LI}}$ is the annual change in carbon stock storage in litter;

$\Delta \mathrm{C}_{\mathrm{SO}}$ is the annual change in carbon stock storage in soil organic matter;

$\Delta \mathrm{C}_{\mathrm{HWP}}$ is the annual change in carbon stock storage in harvested wood products
If it can be assumed that $\left(\Delta \mathrm{C}_{\mathrm{AB}}+\Delta \mathrm{C}_{\mathrm{BB}}\right)=\Delta \mathrm{NPP}$, and that the sum of $\left(\Delta \mathrm{C}_{\mathrm{DW}}+\Delta \mathrm{C}_{\mathrm{LI}}+\Delta \mathrm{C}_{\mathrm{SO}}\right)$ changes slowly and is close to zero over short time periods of less than a decade, then this equation can be simplified and rewritten as:

$$
\Delta \mathrm{C}_{\mathrm{LUi}}=\Delta \mathrm{NPP}+\Delta \mathrm{C}_{\mathrm{HWP}}
$$

Although this accounting method for annual change in forest carbon stocks cannot substitute entirely for a valid ground-based sample inventory of total standing wood

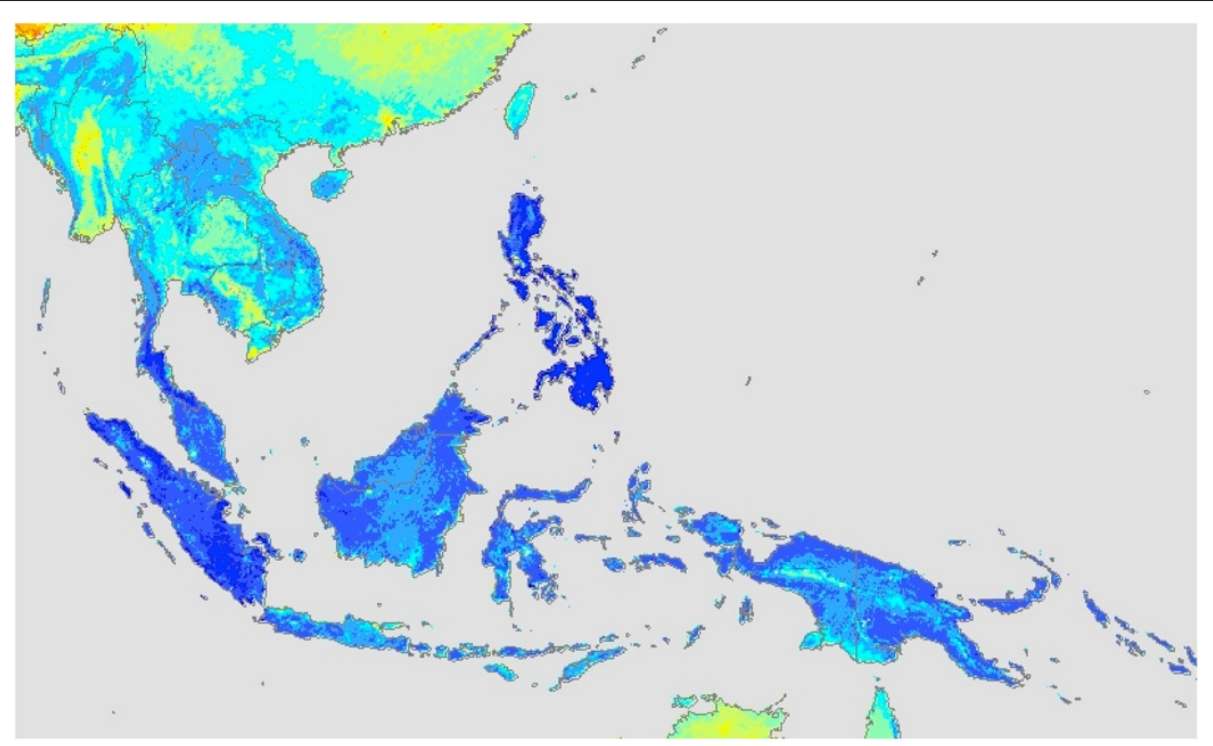

Figure 2 CASA mean NPP flux over the years 2000 to 2010 classified by natural breaks (Jenks' optimization). Legend: Light blue - Low production forest, Medium blue - Moderate production forest, Dark blue - High production forest. 
carbon at any given point in time, it does provide an estimate of the change in forest ecosystem carbon storage on a yearly basis. If the $\mathrm{C}_{\mathrm{HWP}}$ amount is known over a welldefined management area with a high level of confidence for a given year, then the difference between annual NPP and $\mathrm{C}_{\mathrm{HWP}}$ fluxes becomes an estimate of the change in total carbon stocks for that forest area during that year.

As long as total annual NPP flux exceeds annual $\mathrm{C}_{\mathrm{HWP}}$ flux by a factor of between two to three, then a forested area should have a positive carbon stock balance, and a net gain in the inventory of total wood carbon for that year. Therefore, $40 \%$ of annual NPP [1] summed over the projected period of forest management activities in a given area can conservatively define the upper limit for the amount of harvested wood products that can be removed and still avoid degradation (net loss) of the total wood carbon stock over that same time period.

Case studies from throughout the Southeast Asia region for the maximum $\mathrm{C}_{\mathrm{HWP}}$ amount that could be sustainably extracted per year (Table 2) were generated using the CASA model NPP predictions shown in Figure 1. In numerous cases studies derived by IGES [11] reports, emission reduction programs are commonly designed to improve forest management within timber concessions. Sustainable management planning typically has the multiple goals of lowering carbon emissions and improving forest health, while still profiting from harvested wood products. Three of the case study projects from Table 2 were explored in more detail below to illustrate the utility of CASA model predictions for establishing sustainable $\mathrm{C}_{\text {HWP }}$ limits.

In the Berau District, East Kalimantan, Indonesia, The Nature Conservancy has been working since 2006 to promote sustainable harvesting practices through the Responsible Asian Forestry and Trade Program (RAFT). Eight of the district's 13 timber concessions are working with the Conservancy to improve their forest management by setting aside high conservation value forests, adopting reduced impact logging techniques, and tracking their timber. A stated goal of the project is to avoid emissions of 10 million tons $(\mathrm{Mt})$ of $\mathrm{CO}_{2}$ over five years. Conversion from $\mathrm{Mt} \mathrm{CO}_{2}$ equivalent to $\mathrm{Mt} \mathrm{C}$ (by the factor of 12/44) puts the goal at about $2.7 \mathrm{Mt} \mathrm{C}$ in avoided forest carbon emissions from the project area. The estimated sustainable maximum $\mathrm{C}_{\mathrm{HWP}}$ amount of

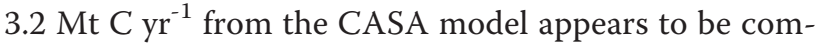
patible with this avoided emissions goal.

The Oddar Meanchey Province Community Forestry Initiative for Carbon and Biodiversity Conservation and Poverty Reduction in northern Cambodia estimated that sustainable management and forest protection would result in a net annual stock change of $0.03 \mathrm{Mt} \mathrm{C}$ (about $0.11 \mathrm{Mt} \mathrm{CO}_{2}$ equivalent $\mathrm{yr}^{-1}$ ) over the first 10 years of the project. This is well below the estimated sustainable

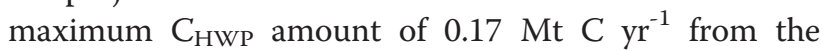
CASA model for this project area.

The Leuser Ecosystem in Aceh Province, Sumatra, Indonesia is considered to be one of the last places in

Table 2 Case studies from the Southeast Asia region (Source: IGES, [11]) for the maximum $\mathrm{C}_{\mathrm{HWP}}$ amount that could be sustainably extracted per year

\begin{tabular}{|c|c|c|c|c|c|c|c|}
\hline \multirow[t]{2}{*}{ Project name } & \multirow[t]{2}{*}{ Location } & \multirow[t]{2}{*}{$\begin{array}{l}\text { Coordinates } \\
\text { (lat, lon dd) }\end{array}$} & \multirow[t]{2}{*}{$\begin{array}{l}\text { Area managed } \\
\text { (ha) }\end{array}$} & \multicolumn{2}{|l|}{$\begin{array}{l}\text { CASA NPP } \\
\left.\text { (t C } \mathrm{ha}^{-1} \mathrm{yr}^{-1}\right)\end{array}$} & \multicolumn{2}{|c|}{$\begin{array}{l}\text { Limit for sustainable wood } \\
\text { extraction } \\
\mathrm{C}_{\mathrm{HWP}}\left(\mathrm{Mt} \mathrm{C} \mathrm{yr}^{-1} \text { ) }\right.\end{array}$} \\
\hline & & & & Mean & Stdev & Total & $+/-$ \\
\hline $\begin{array}{l}\text { Leuser Ecosystem } \\
\text { Project }\end{array}$ & $\begin{array}{l}\text { Aceh Province, Sumatra, } \\
\text { Indonesia }\end{array}$ & $3.9369,97.1807$ & $1,920.00$ & 8.95 & 0.55 & 6.70 & 0.41 \\
\hline $\begin{array}{l}\text { Berau Forest } \\
\text { Carbon Program }\end{array}$ & $\begin{array}{l}\text { East, Kalimantan, } \\
\text { Indonesia }\end{array}$ & $1.9030,117.1028$ & 800,000 & 10.30 & 0.40 & 3.21 & 0.12 \\
\hline $\begin{array}{l}\text { Kamula Doso } \\
\text { Carbon Project }\end{array}$ & $\begin{array}{l}\text { Western Province, } \\
\text { Papua New Guinea }\end{array}$ & $-7.2072,141.9814$ & 791,200 & 10.12 & 0.35 & 3.12 & 0.11 \\
\hline $\begin{array}{l}\text { April Salumei } \\
\text { Forest project }\end{array}$ & $\begin{array}{l}\text { Eat Sepik Province } \\
\text { Papau New Guine }\end{array}$ & $-4.6339,142.7888$ & 521,000 & 9.76 & 0.38 & 1.98 & 0.80 \\
\hline $\begin{array}{l}\text { Cat Tien National } \\
\text { Park Buffer Zone }\end{array}$ & $\begin{array}{l}\text { Lam dong Province, } \\
\text { Vietnam }\end{array}$ & $11.7670,107.5900$ & 251,445 & 8.94 & 0.57 & 0.88 & 0.06 \\
\hline $\begin{array}{l}\text { Kalimantan forests } \\
\& \text { Climate }\end{array}$ & $\begin{array}{l}\text { Central Kalimantan, } \\
\text { Indonesia }\end{array}$ & $-2.0417,114.5364$ & 120,000 & 8.97 & 0.46 & 0.42 & 0.02 \\
\hline $\begin{array}{l}\text { Community Forestry } \\
\text { Iniative }\end{array}$ & $\begin{array}{l}\text { Oddar Meanchey Province, } \\
\text { Indonesia }\end{array}$ & $14.3668,103.4292$ & 61,826 & 7.15 & 0.37 & 0.17 & 0.01 \\
\hline $\begin{array}{l}\text { Merang Peat Swamp } \\
\text { Forest }\end{array}$ & $\begin{array}{l}\text { South Sumatra Province, } \\
\text { Indonesia }\end{array}$ & $-2.0000,104.0030$ & 24,000 & 10.79 & 0.88 & 0.10 & 0.01 \\
\hline
\end{tabular}

Projects are listed by potential area under management, highest to lowest. Units for NPP are tons carbon per hectare per year (t $\mathrm{C}$ ha $\left.{ }^{-1} \mathrm{yr}^{-1}\right)$ and for maximum

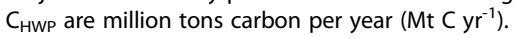


Southeast Asia of sufficient size and quality to maintain viable populations of many rare animal species such as tigers, orangutans, rhinos, elephants, and clouded leopard.

Under Indonesian law, it is illegal to undertake any activities inside the Leuser Ecosystem that are not directly related to either the protection or restoration of the ecosystem. The main driving forces of forest loss in the province include poorly controlled infrastructure development, mining, and conversion to tree crop plantations, namely palm oil.

In management planning reports for the area (IGES, [11]), carbon stocks of forests were estimated at an average of $760 \mathrm{t} \mathrm{CO}_{2}$ equivalent ha ${ }^{-1}\left(207 \mathrm{t} \mathrm{C} \mathrm{ha}^{-1}\right)$. With an estimated 1,920,000 ha of forested land in the Leuser Ecosystem, this totals to roughly $396 \mathrm{Mt} \mathrm{C}$ in projected carbon stock, and an average of $17 \mathrm{Mt} \mathrm{C} \mathrm{yr}^{-1}$ in NPP from the CASA model. Consequently, the sustainable maximum $\mathrm{C}_{\mathrm{HWP}}$ from the CASA model would be 6.7 $\mathrm{Mt} \mathrm{C} \mathrm{yr}^{-1}$ for the entire Leuser Ecosystem area.

In summary, we have shown in this study that MODIS satellite data has been collected at the broad scale required for useful national estimates of forest carbon production. The daily repeat frequency of MODIS data acquisitions makes this sensor essential to overcome persistent cloud cover for observations of the land surface in tropical Southeast Asia. We have also used Landsat imagery in the same way with the CASA model to monitor forest production and potential degradation at finer scales, such as described in the study by Potter et al. [12].

\section{Conclusions}

- The method of using CASA model's estimated annual change in forest carbon on a yearly basis can conservatively define the upper limit for the amount of harvested wood products that can be removed and still avoid degradation (net loss) of the total wood carbon stock over that same time period.

- The countries with the highest average forest NPP over the period 2000 to 2010 were the Philippines, Malaysia and Indonesia.

- Highest estimated NPP (at greater than $1100 \mathrm{~g} \mathrm{C} \mathrm{m}^{-2} \mathrm{yr}^{-1}$ ) was detected in the southern Philippines, particularly the eastern and southern sections of the island of Mindanao, the Khao Luang mountain range in southern Thailand, and most forested areas of Sumatra and western Kalimantan.

\section{Methods}

Monthly NPP of vegetation from the CASA model was predicted using the relationship between greenness reflectance properties and the fraction of absorption of photosynthetically active radiation (fPAR), assuming that net conversion efficiencies of PAR to plant carbon can be approximated for different ecosystems or are nearly constant across all ecosystems [13-15]. For this study, we used MODIS collection 5 of the Enhanced Vegetation Index (EVI; Huete, et al. [16]) as model inputs for PAR interception, aggregated for regional assessments of cloud-free imagery to an 8-km spatial resolution.

As documented in Potter [17], monthly production of plant biomass is estimated as a product of time-varying surface solar irradiance, Sr, and EVI (for fPAR) from the MODIS sensor, plus a constant light utilization efficiency term (emax) that is modified by time-varying stress scalar terms for temperature $(\mathrm{T})$ and moisture (W) effects (Equation 1).

$$
\mathrm{NPP}=\mathrm{S}_{\mathrm{r}} \mathrm{EVI} \mathrm{e}_{\max } \mathrm{T} \mathrm{W}
$$

The CASA emax term was set uniformly at $0.55 \mathrm{~g} \mathrm{C}$ $\mathrm{MJ}^{-1}$ PAR, an approach that derives from calibration of predicted annual NPP to previous field estimates [3]. This model setting has been successfully validated globally by comparing predicted annual NPP to more than 1900 field measurements of NPP [4], and against numerous Fluxnet eddy covariance tower site measurements of NPP from 2000-2007 [5]. Gridded monthly climate inputs for these CASA runs were from National Center for Environmental Prediction (NCEP) reanalysis products (version NCEP/DOE II; [18]).

\section{Competing interests}

The authors declare that they have no competing interests.

\section{Authors' contributions}

All authors have made substantial contributions to the acquisition of data, analysis and interpretation of results, drafting the manuscript, and have given final approval of the version to be published.

\section{Acknowledgments}

This work was supported by funding from NASA Ames Research Center and the NASA contributions to the United States SilvaCarbon Program (online at swp.gmu.edu/silvacarbon/). CASA model NPP predictions used in this study for forests worldwide are available online at http://geo.arc.nasa.gov/sge/casa/ cquestwebsite/.

\section{Author details}

${ }^{1}$ NASA Ames Research Center, Moffett Field, CA, USA. ${ }^{2}$ California State University Monterey Bay, Seaside, CA, USA.

Received: 3 April 2013 Accepted: 20 June 2013

Published: 10 September 2013

\section{References}

1. Malhi Y, Doughty $C$, Galbraith D: The allocation of ecosystem net primary productivity in tropical forests. Phil Trans R Soc B 2011, 366:3225-3245.

2. Luo YQ, White LW, Canadell JG, et al: Sustainability of terrestrial carbon sequestration: a case study in Duke Forest with inversion approach. Global Biogeochem Cycles 2003, 17:1-3.

3. Potter CS, Randerson JT, Field CB, Matson PA, Vitousek PM, Mooney HA, Klooster SA: Terrestrial ecosystem production: a process model based on global satellite and surface data, Global Biogeochem. Global Biogeochem Cycles 1993, 7:811-841.

4. Potter C, Klooster S, Myneni R, Genovese V, Tan P, Kumar V: Continental scale comparisons of terrestrial carbon sinks estimated from satellite data and ecosystem modeling 1982-98. Global Planet Change 2003, 39:201-213 
5. Potter C, Klooster S, Genovese V: Net primary production of terrestrial ecosystems from 2000 to 2009. Clim Change 2012. doi:10.1007/s10584-012-0460-2.

6. Zhao M, Running SW: Drought-induced reduction in global terrestrial net primary production from 2000 through 2009. Science 2010, 329:940-943.

7. Miettinen J, Shi C, Liew SC: Deforestation rates in insular Southeast Asia between 2000 and 2010. Glob Chang Biol 2011, 17:2261-2270.

8. Potter C, Klooster S, Genovese V, Hiatt C, Boriah S, Kumar V, Mithal V, Garg A: Terrestrial ecosystem carbon fluxes predicted from MODIS satellite data and large-scale disturbance modeling. Int J Geosci 2012. doi:10.4236/ijg.2012.

9. Jenks GF: The data model concept in statistical mapping. International Yearbook of Cartography 1967, 7:186-190.

10. Intergovernmental Panel on Climate Change (IPCC), et al: Good practice guidance for land use, land-use change and forestry (GPG-LULUCF). In Edited by Penman J. IPCC National Greenhouse Gas Inventories Programme, Technical Support Unit, Hayama, Kanagawa, Japan; 2003. Available online at www.ipcc-nggip.iges.or.jp/public/gpglulucf/gpglulucf_contents.

11. Institute for Global Environmental Strategies (IGES): REDD+ Database Kamiyamaguchi, Hayama, Kanagawa, Japan; 2013. Available online at http:// redd-database.iges.or.jp/redd/.

12. Potter C, Gross P, Genovese V, Smith M-L: Net primary productivity of forest stands in New Hampshire estimated from Landsat and MODIS satellite data. Carbon Balance and Management 2007, 2:9.

13. Sellers PJ, Tucker CJ, Collatz GJ, Los SO, Justice CO, Dazlich DA, Randall DA: A global 1x1 NDVI data set for climate studies. Part 2: the generation of global fields of terrestrial biophysical parameters from the NDVI. Int $J$ Remote Sens 1994, 15:3519-3545.

14. Goetz SJ, Prince SD: Variability in light utilization and net primary production in boreal forest stands. Can J Forest Res 1998, 28:375-389

15. Running SW, Nemani RR, Heinsch FA, Zhao M, Reeves M, Hashimoto H: A continuous satellite-derived measure of global terrestrial primary production. Bioscience 2004, 54:547-560.

16. Huete AR, Didan K, Shimabukuro YE, Ratana P, Saleska SR, Hutyra LR, Fitzjarrald D, Yang W, Neman RR, Myneni R: Amazon rainforests green-up with sunlight in dry season. Geophys Res Lett 2006, 33:L 06405. doi:10.1029/2005GL025583.

17. Potter CS: Terrestrial biomass and the effects of deforestation on the global carbon cycle. Bioscience 1999, 49:769-778.

18. Kistler $R$, et al: The NCEP-NCAR 50-year reanalysis: monthly means CD-ROM and documentation. Bull Am Meteorol Soc 2001, 82:247-268.

doi:10.1186/1750-0680-8-9

Cite this article as: Potter et al:: Forest production predicted from satellite image analysis for the Southeast Asia region. Carbon Balance and Management 2013 8:9.

\section{Submit your next manuscript to BioMed Central and take full advantage of:}

- Convenient online submission

- Thorough peer review

- No space constraints or color figure charges

- Immediate publication on acceptance

- Inclusion in PubMed, CAS, Scopus and Google Scholar

- Research which is freely available for redistribution 